\title{
Cool-Season Turfgrass Species and Cultivars: Response to Simulated Traffic in Central Italy
}

\author{
Carlo F. Cereti, Roberto Ruggeri*, Francesco Rossini \\ Department of Crop Production, University of Tuscia \\ Via San Camillo de Lellis, 01100 Viterbo, Italy
}

Received: 14 September 2009. Accepted: 3 December 2009.

\begin{abstract}
Turfgrass species differ greatly in their ability to withstand the abrasion and compaction of traffic. Wear tolerance of turfgrass species and cultivars has been evaluated abroad by many researchers, while only few and partial studies have been conducted in Italy.

Field experiment was carried out in Viterbo in 2001, 2002 and 2003 to evaluate the effect of the simulated traffic on 110 varieties belonging to four turfgrass cool-season species: tall fescue (Festuca arundinacea Schreb.), fine fescues (Festuca rubra L. ssp. rubra Gaud., ssp. commutata Gaud., ssp. tricophylla Gaud.), perennial ryegrass (Lolium perenne L.) and Kentucky bluegrass (Poa pratensis L.). Shoot density, visual turfgrass quality and thatch thickness were the major characters recorded to estimate wear tolerance.

Traffic was simulated using a device containing three rollers pulled by a small tractor. The traffic simulator weighed $564 \mathrm{~kg}$ and applied a pressure of about $3 \mathrm{MPa}$.

Results indicated that perennial ryegrass and tall fescue had high wear tolerance and low statistical variation among cultivars. Kentucky bluegrass showed an average wear tolerance owing to its shoot density and good recovery potential. In spite of their high shoot density, fine fescues exhibited poor wear tolerance because of their scarce resistance to high temperatures which are typical of the Mediterranean climate in late spring and summer.

This study enabled a preliminary selection of the most suitable cool-season grasses and cultivars for trafficked and non-trafficked areas in Central Italy and highlighted that different turfgrass species have different wear tolerance mechanisms.
\end{abstract}

Key-words: fine fescues, Kentucky bluegrass, perennial ryegrass, tall fescue, traffic tolerance, turfgrass cultivars.

\section{Introduction}

Traffic is defined as injury to a turfgrass stand from pressure, tearing, and scuffing directly on the tissues (Carrow and Petrovic, 1992) caused by players, heavy machinery, grazing animals, etc.

At first more importance was given to the effect of soil compaction caused by traffic, rather than to the wear injury on turf vegetation, and it was thought that the problem could be solved, to a large extent, by the introduction of the sandy substrate.

Subsequently, researchers focused their studies on vegetation wear tolerance mechanisms because of the technical and economic difficulties to change the growing media of the major recreation areas and orchards, the innumerable problems encountered in the sport fields subjected to frequent use, and the increasingly strong competition of synthetic materials as substrate for the sport activities (Noè and Passini, 2009).

The tolerance to this stress depends on several factors including tiller density, thickness of the thach layer, speed of regrowth and potential for recovery of herbaceous vegetation (Shildrick, 1974; Sherman and Beard, 1975).

The demand for traffic tolerant turfgrasses has increased due to the increased use of sport fields, parks, golf courses and other recreational areas.

In sport fields and in the recreation and urban green areas, the good utilization of turfgrass and the quality of sport activities are often im-

\footnotetext{
* Corresponding Author: Tel.: +39 0761 357560; Fax: +39 0761 357558. E-mail address: r.ruggeri@unitus.it
} 
paired by wear damages, mainly in winter, when the potential for recovery of grass is low, and especially in the much trafficked areas (Cereti et al., 2002, 2003).

Turfgrass species differ greatly in their ability to withstand the abrasion and compaction of traffic (Gaussoin, 1994). Wear tolerance of turfgrass species and mixtures has been evaluated abroad by a number of researchers (Bourgoin and Mansat, 1982; Canaway, 1981; Fushtey et al., 1982; Taivalmaa et al., 1998). Evaluation of cultivars within given species has also been conducted (Evans, 1988; Minner et al., 1993; Wood and Law, 1972), although data on recently developed cultivars is limited.

Performances of turfgrass cultivars under traffic were greatly affected by the growing environment (Bonos et al., 2001). Thus, conducting wear tolerance trials under different management regimes, soil properties, climates and regions is necessary.

On the contrary, in Italy we needed yet a wide characterization of turfgrass species and cultivars in the different climatic conditions above all on the traffic tolerance aspects.

The aim of this study was to evaluate four cool-season turfgrass species under traffic and non traffic-conditions and to identify cultivars of Kentucky bluegrass, perennial ryegrass, fine fescues and tall fescue with superior wear tolerance, in order to recommend them for imple- mentation of sport fields, parks and recreation areas in Central Italy.

\section{Materials and methods}

In this study 110 varieties belonging to four cool-season turfgrass species were evaluated for their traffic tolerance: 20 cultivars of tall fescue (Festuca arundinacea Schreb.), 30 cultivars of fine fescues (Festuca rubra L.), 40 cultivars of perennial ryegrass (Lolium perenne L.) and 20 cultivars of Kentucky bluegrass (Poa pratensis L.). Fine fescues included three subspecies (ssp): Chewings fescue ( $F$. rubra L. ssp. commutata Gaud.) (10 cultivars), strong creeping red fescue (F. rubra L. ssp. rubra Gaud.) (10 cultivars) and slender creeping red fescue (F. rubra L. ssp. tricophylla Gaud.) (10 cultivars). The list of the tested cultivars is shown in Table 1.

All species were established from seed three years prior to superimposing the wear treatments. All of them were maintained at a cutting height of $3.5 \mathrm{~cm}$ and were mowed once or twice weekly (depending on the season) with the clippings bagged by a riding reel mowers. Nitrogen fertilization was applied each year providing a total of $150 \mathrm{~kg} \mathrm{~N} \mathrm{ha}^{-1}$, with no single nitrogen application exceeding $50 \mathrm{~kg} \mathrm{~N}$ ha $^{-1}$. Irrigation was applied to prevent visual wilt symptoms, with a replacement level of Maximum Evapo-

Table 1. Turfgrass species and cultivars used in the study.

\begin{tabular}{|c|c|c|c|c|c|}
\hline \multirow{2}{*}{$\frac{\text { Tall fescue }}{\text { Amalia }}$} & \multicolumn{2}{|c|}{ Fine fescues } & \multicolumn{2}{|c|}{ Perennial ryegrass } & \multirow{2}{*}{$\frac{\text { Kentucky bluegrass }}{\text { Alpine }}$} \\
\hline & Ch. fescue & Rubina & Accolade & Kelvin & \\
\hline Asterix & Bargreen & Rudax & Advent & Leon & Balin \\
\hline Barbizon & Carina & sl.c.r. fescue & Amadeus & Lex86 & Barcelona \\
\hline Cochise & Center & Barcrown & Athena & Lisabelle & Bartitia \\
\hline Eldorado & Licato & Bornado & Barcredo & Livonne & Cocktail \\
\hline Elegance & Olivia & Dawson & Barrage & Lorettanova & Compact \\
\hline Emperor & Rainbow & Estica & Brightstar & Marabelle & Conni \\
\hline Houndog & Samt & Liprosa & Caddy & Milton & Cynthia \\
\hline Lara & Tatjana & Lovisa & Capri & Montreaux & Eva \\
\hline Matador & Waldorf & Napoli & Chagall & Numan & Fortuna \\
\hline Miro & Wilma & Rufilla & Chaparral & Palmer & Haga \\
\hline Murray & st.c.r. fescue & Seabreeze & Charger2 & Pazsit & Midnight \\
\hline Olga & Barcorsa & Suzette & Concerto & Pickwick & Miracle \\
\hline Regiment & Felix & & Darius & Rival & Moonlight \\
\hline Safari & Franklin & & Envy & Roadrunner & Optigreen \\
\hline Sinfonia & Gentil & & Essence & Ronja & Princeton \\
\hline Strand & Kristina & & Fragment & Sublime & Saskia \\
\hline Tarheel & Laxton & & Gator & Talgo & Stola \\
\hline Titan & Pernilla & & Henrietta & Titus & Szarvas \\
\hline Villageoise & Robin & & Kaiser & Verdi & Unique \\
\hline
\end{tabular}




\begin{tabular}{|c|c|c|c|}
\hline & \multicolumn{3}{|c|}{ depth $(\mathrm{cm})$} \\
\hline & $0-10$ & $11-20$ & $21-30$ \\
\hline Corse sand $(0.2<\varnothing<2 \mathrm{~mm})$ & $25.40 \%$ & $24.60 \%$ & $25.40 \%$ \\
\hline Fine sand $(0.02<\varnothing<0.2 \mathrm{~mm})$ & $35.20 \%$ & $33.30 \%$ & $34.00 \%$ \\
\hline Silt $(0.002<\varnothing<0.02 \mathrm{~mm})$ & $19.10 \%$ & $21.00 \%$ & $19.40 \%$ \\
\hline Clay $(\varnothing<0.002 \mathrm{~mm})$ & $20.30 \%$ & $21.00 \%$ & $21.20 \%$ \\
\hline Nitrogen $(\mathrm{N})$ & $0.101 \%$ & $0.097 \%$ & $0.091 \%$ \\
\hline Organic matter (om) & $1.40 \%$ & $1.10 \%$ & $1.10 \%$ \\
\hline $\mathrm{pH}$ & 6.8 & 6.9 & 7.0 \\
\hline Calcium carbonate $\left(\mathrm{CaCO}_{3}\right)$ & $0 \%$ & $0 \%$ & $0 \%$ \\
\hline
\end{tabular}

transpiration (ETM) equal to $80 \%$. ETM was computed by correcting reference ET $\left(\mathrm{ET}_{0}\right)$ with a crop coefficient $(\mathrm{Kc})$ equal to 0.8 , where $\mathrm{ET}_{0}$ was computed, in turn, by means of the simplified form of the FAO Penman Monteith Equation for use with 24-h time steps (Allen et al., 1994, 1998). Climatic parameters necessary for $\mathrm{ET}_{0}$ calculation were obtained from the weather station at the Experimental Farm of the University of Tuscia in Viterbo. The selection of the Kc value was made on the basis of national and international references (Cereti, 2002; Meyer et al., 1985; Brown et al., 2001; Richie et al., 2002).

The research was carried out in Viterbo $\left(42^{\circ}\right.$ $26^{\prime} \mathrm{N}, 12^{\circ} 04^{\prime} \mathrm{E}$, altitude $310 \mathrm{~m}$ asl) from 2001 to 2003 on a sandy-clayey soil. Main soil properties are shown in Table 2 for a maximum depth of $30 \mathrm{~cm}$.

A split-split-plot experimental design with three replications was used. Main plot treatments consisted of four turfgrass species. Subplots were 110 cultivars and sub-sub-plots were traffic and non-traffic treatments.

Traffic was initiated in late spring 2001 using a modified Brinkman Traffic Simulator (Cockerham and Brinkman, 1989) containing three rollers pulled by a small tractor. Two rollers were studded (14 mm studs), geared to turn at different speeds to simulate the tearing action at the turfgrass surface, while the other one was smooth to simulate pression and compaction effects. The traffic simulator was designed by the University of Padua and built by the Department of Agronomy, Forest and Land Management of the University of Turin. It weighed $564 \mathrm{~kg}$ and applied a pressure of about $3 \mathrm{MPa}$. Turfgrass species and cultivars were subjected weekly to wear treatment which was ap- plied on each date by passing over one-half of each sub-plot $(1.5 \times 2 \mathrm{~m})$ two times. According to the research conducted by Reyneri and Bruno (2003), this treatment simulated two matches per week during December-January and four matches per week in the other months.

Visual turfgrass quality, shoot density and thatch thickness were recorded in 2002 and 2003 to evaluate traffic tolerance. Visual quality measurements were taken monthly using a 1 to 9 scale. Nine indicated perfect turf in terms of uniformity, colour, health of grass, etc. One indicated a complete loss of turfgrass coverage and colour. Five is acceptable for a low budget facility and six would be the minimal acceptable level of a higher budget facility. Turfgrass quality ratings were taken both on worn and unworn portions of each sub-plot. Shoot density and thach thickness were measured in 2002 and 2003 in spring and autumn both in trafficked and non-trafficked portions of the sub-plots. Both measurements were made by taking a $10 \mathrm{~cm}$ deep by $5.8 \mathrm{~cm}$ diameter core from each subsub-plot.

All data were subjected to analysis of variance and means were separated using the Fisher's protected least significant difference (LSD).

\section{Results and discussion}

\section{Visual turfgrass quality}

Perennial ryegrass was the only species that obtained a high score in each season, while fine fescues never reached a sufficient value of visual turfgrass quality (Fig. 1). This result may be consistent with those by Taivalmaa et al. (1998), who found that fine fescues disappeared after three years of intensive wear. Tall fescue was be- 


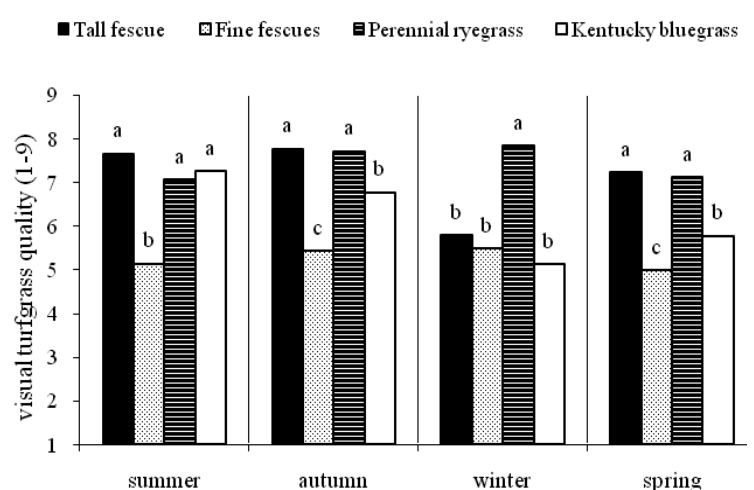

Figure 1. 2002-2003 Average turf quality ratings obteined by four cool-season turfgrass species under traffic for each season in Viterbo (in each season, scores not having any letter in common are significantly different at $\mathrm{P} \leq 0.05)$.

low an acceptable level of visual turfgrass quality only in winter because of its scarce tolerance to low temperatures, but it was the best species in the other seasons, and especially in summer. These results were in agreement with the observation that large tillers are more likely to survive wear and compaction than smaller ones (Carrow, 1980; Parr, 1981; O’Neil and Carrow, 1982, 1983; Shildrick and Peel, 1984a, b). A good visual turfgrass quality was observed for Kentucky bluegrass in summer thanks to the abundant rainfalls in the first ten days of August 2002, while unacceptable turfgrass quality in winter was associated both to yellow-coloured leaves caused by a rust disease (Puccinia spp.) and purple and/or straw coloration displayed by some cultivars during long winter dormancy (Bonos et al., 2003).

In non-trafficked plots the results were very similar, with the only difference that scores of visual turfgrass quality were somewhat lower than those under traffic for perennial ryegrass (Fig. 2). This finding was in agreement with research by Park et al. (2003) who noted that many perennial ryegrass cultivars that performed well under traffic could not exhibit the most pleasing aesthetic characteristics in non trafficked plots.

Houndog, Olga and Regiment for tall fescue, Kristina and Pernilla for fine fescues, Athena, Advent and Milton for perennial ryegrass, and Haga and Cynthia for Kentucky bluegrass showed greater and consistent traffic tolerance (Tab. 3).

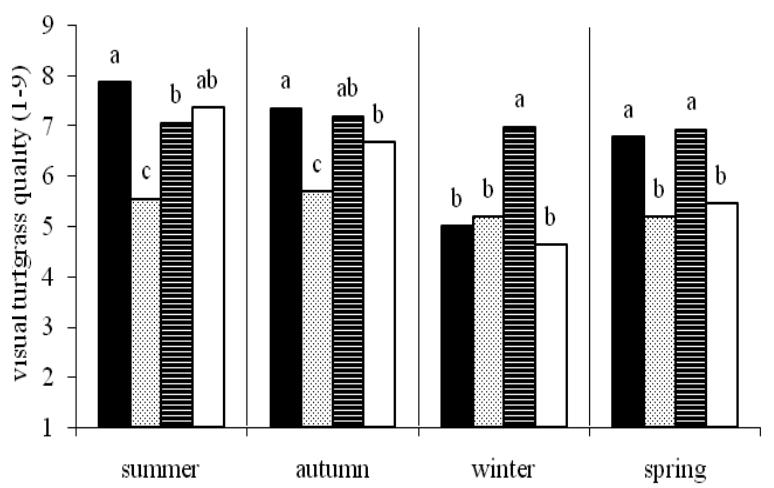

Figure 2. 2002-2003 Average turf quality ratings obteined by four cool-season turfgrass species under non-traffic for each season in Viterbo (in each season, scores not having any letter in common are significantly different at $\mathrm{P} \leq 0.05)$.

Tall fescue and perennial ryegrass showed limited among-varieties variation either in worn or unworn plots so that many cultivars could be selected for both trafficked and non-trafficked turfgrasses.

\section{Shoot density}

The different turfgrass species showed significantly different shoot density, with the highest values for fine fescues and the lowest ones for tall fescue (data not shown). The traffic treatment effect was also significant and highlighted greater shoot density in non-trafficked plots compared to the trafficked ones (data not shown).

The traffic treatment by species interaction effect on shoot density was not significant.

Within trafficked plots, shoot density of turfgrass species was compared after dividing the fine fescues into their three subspecies. In general, shoot density was greatest for Chewings fescue, followed by slender creeping red fescue and least for strong creeping red fescue, which is not significantly different from perennial ryegrass and Kentucky bluegrass shoot density (Fig. 3). This result confirmed what Taivalmaa et al. (1998) found about the highest tiller densities of fine fescues varieties in Finland. Trafficked Kentucky bluegrass also showed a good shoot density, not significantly different from slender creeping red fescue, strong creeping red fescue and perennial ryegrass, thanks to the development of its vigorous rhizomes. This finding and the good visual turfgrass quality of traf- 
Table 3. 2002-2003 Average turf quality ratings obteined by the best five cultivars of cool-season grasses under traffic for each season in Viterbo (in each season, scores not having any letter in common are significantly different at $\mathrm{P} \leq 0.05$ ).

\begin{tabular}{|c|c|c|c|c|c|c|c|c|}
\hline \multirow[b]{2}{*}{ Species } & \multicolumn{2}{|c|}{ Summer } & \multicolumn{2}{|c|}{ Autumn } & \multicolumn{2}{|c|}{ Winter } & \multicolumn{2}{|c|}{ Spring } \\
\hline & Cultivars & $\begin{array}{l}\text { Average } \\
\text { Turf } \\
\text { Quality* }\end{array}$ & Cultivars & $\begin{array}{l}\text { Average } \\
\text { Turf } \\
\text { Quality* }\end{array}$ & Cultivars & $\begin{array}{l}\text { Average } \\
\text { Turf } \\
\text { Quality* }\end{array}$ & Cultivars & $\begin{array}{l}\text { Cultivars } \\
\text { Turf } \\
\text { Quality* }\end{array}$ \\
\hline \multirow[t]{5}{*}{ Tall fescue } & Titan & $8.3 \mathrm{a}$ & Eldorado & $8.2 \mathrm{a}$ & Regiment & $6.0 \mathrm{fk}$ & Houndog & $7.7 \mathrm{ac}$ \\
\hline & Olga & $8.1 \mathrm{ab}$ & Houndog & $8.0 \mathrm{ab}$ & Amalia & $5.9 \mathrm{gl}$ & Sinfonia & 7.4 ae \\
\hline & Houndog & $8.0 \mathrm{ac}$ & Regiment & $8.0 \mathrm{ab}$ & Olga & $5.9 \mathrm{gl}$ & Eldorado & 7.3 af \\
\hline & Strand & 7.9 ad & Strand & $8.0 \mathrm{ab}$ & Tar Heel & $5.9 \mathrm{gl}$ & Olga & 7.3 af \\
\hline & Tar Heel & 7.9 ad & Villageoise & $8.0 \mathrm{ab}$ & Villageoise & $5.9 \mathrm{gl}$ & Regiment & 7.3 af \\
\hline \multirow[t]{5}{*}{ Fine fescues } & Carina & $5.8 \mathrm{ip}$ & Gentil & $6.0 \mathrm{gl}$ & Kristina & $6.6 \mathrm{bg}$ & Olivia & 6.1 fo \\
\hline & Samt & $5.8 \mathrm{ip}$ & Kristina & $6.0 \mathrm{gl}$ & Gentil & $6.4 \mathrm{ch}$ & Carina & $5.8 \mathrm{hq}$ \\
\hline & Laxton & 5.7 jp & Dawson & $5.8 \mathrm{hl}$ & Estica & $6.3 \mathrm{di}$ & Pernilla & 5.7 ir \\
\hline & Kristina & $5.4 \mathrm{kq}$ & Napoli & $5.8 \mathrm{hl}$ & Suzette & $6.2 \mathrm{ej}$ & Center & 5.6 js \\
\hline & Center & $5.4 \mathrm{kq}$ & Pernilla & $5.8 \mathrm{hl}$ & Pernilla & $6.0 \mathrm{fk}$ & Samt & 5.6 js \\
\hline \multirow[t]{5}{*}{ Perennial ryegrass } & Athena & 7.7 af & Athena & $8.3 \mathrm{a}$ & Athena & $8.2 \mathrm{a}$ & Athena & $8.0 \mathrm{a}$ \\
\hline & Milton & 7.7 af & Advent & $8.2 \mathrm{a}$ & Chaparral & $8.2 \mathrm{a}$ & Fragment & $7.8 \mathrm{ab}$ \\
\hline & Lex86 & 7.6 af & Fragment & $8.2 \mathrm{a}$ & Advent & $8.1 \mathrm{a}$ & Milton & $7.8 \mathrm{ab}$ \\
\hline & Lorettanova & 7.6 af & Sublime & 8.2 a & Essence & $8.1 \mathrm{a}$ & Advent & $7.7 \mathrm{ac}$ \\
\hline & Montreaux & 7.6 af & Barrage & $8.0 \mathrm{ab}$ & Milton & $8.1 \mathrm{a}$ & Marabelle & $7.7 \mathrm{ac}$ \\
\hline \multirow[t]{5}{*}{ Kentucky bluegrass } & Fortuna & $7.9 \mathrm{ad}$ & Haga & $7.7 \mathrm{ad}$ & Compact & $6.1 \mathrm{fk}$ & Haga & $6.6 \mathrm{bl}$ \\
\hline & Midnight & $7.9 \mathrm{ad}$ & Princeton & 7.3 ae & Szarvas & $6.0 \mathrm{fk}$ & Szarvas & $6.6 \mathrm{bl}$ \\
\hline & Barcelona & 7.8 ae & Cynthia & 7.2 bf & Cynthia & $5.8 \mathrm{gm}$ & Miracle & $6.3 \mathrm{dm}$ \\
\hline & Alpine & 7.7 af & Fortuna & $7.2 \mathrm{bf}$ & Haga & $5.6 \mathrm{go}$ & Optigreen & $6.3 \mathrm{dm}$ \\
\hline & Cynthia & 7.7 af & Balin & $7.0 \mathrm{bg}$ & Unique & $5.6 \mathrm{go}$ & Cynthia & 6.2 en \\
\hline
\end{tabular}

* 1-9 scale: 9 = best quality.

ficked Kentucky bluegrass and perennial ryegrass suggested that wear tolerance is increased as shoot density is increased (Shildrick, 1974; Trenholm et al., 2000). The same does not seem to hold true for fine fescues because of their fine leaves, their very scarce tolerance to spring and summer high temperatures of Mediter-

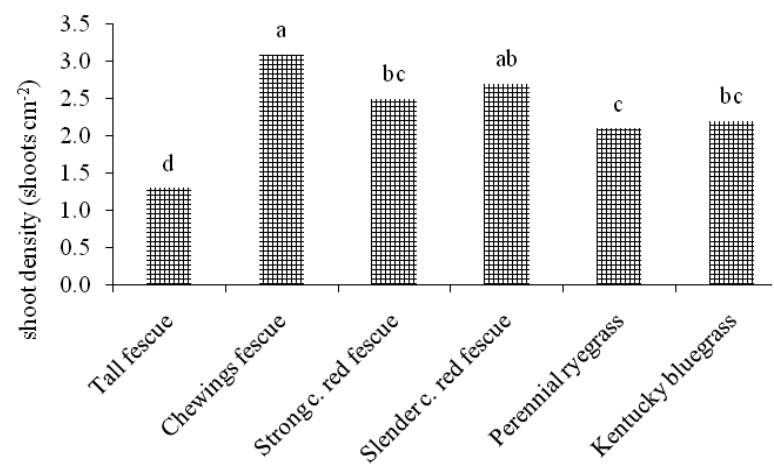

Figure 3. 2002-2003 Average shoot density (shoots $\mathrm{cm}^{-2}$ ) of six cool-season turfgrass species (fine fescues have been divided in to their three sub-species) under traffic in Viterbo (histograms not having any letter in common are significantly different at $\mathrm{P} \leq 0.05$ ). ranean climate and their poor potential of vegetative recovery (especially in slender creeping red fescue and strong creeping red fescue). This highlighted that different turfgrass species had different wear tolerance mechanisms (Shearman and Beard, 1975; Gaussoin, 1994); via the coarse texture for tall fescue and perennial ryegrass, high shoot density and recovery potential for Kentucky bluegrass and Chewings fescue.

The shoot density of the three best varieties under traffic and non-traffic treatment are reported in Table 4. The performance of Midnight, Conni, Rainbow and Tar Heel was consistent with other traffic test conducted abroad (Taivalmaa et al., 1998; Park et al., 2003, 2006). Moreover, Table 4 highlighted that all the best fine fescues varieties in trafficked plots (Waldorf, Carina and Rainbow) belonged to Chewings fescue, confirming data by Bonos et al. (2001) who found that Chewings fescue had better wear tolerance than the other fine fescue subspecies.

\section{Thickness of thatch layer}

Thatch thickness was affected by turfgrass species, showing that Kentucky bluegrass and 
Table 4. 2002-2003 Average shoot density ( shoots $\mathrm{cm}^{-2}$ ) of the best three cultivars of cool-season grasses under traffic and non-traffic conditions in Viterbo.

\begin{tabular}{lcccc}
\hline & \multicolumn{1}{c}{ Trafficked } & & \multicolumn{2}{c}{ Non trafficked } \\
\hline Species & Cultivars & $\begin{array}{c}\text { Shoot Density } \\
\left(\text { shoots } \mathrm{cm}^{-2}\right)\end{array}$ & Cultivars & $\begin{array}{c}\text { Shoot Density } \\
\left(\text { shoots } \mathrm{cm}^{-2}\right)\end{array}$ \\
\hline Tall fescue & Murray & 1.8 & Murray & 2.0 \\
& Asterix & 1.7 & Asterix & 1.9 \\
& Tar Heel & 1.7 & Houndog & 1.8 \\
\hline Fine fescues & Waldorf & 4.6 & Bargreen & 3.9 \\
& Carina & 4.4 & Barcrown & 3.8 \\
\hline Perennial ryegrass & Rainbow & 4.1 & Liprosa & 3.8 \\
\hline Kentucky bluegrass & Concerto & 3.1 & Essence & 3.3 \\
& Lorettanova & 3.0 & Gator & 3.3 \\
& Roadrunner & 2.9 & Chaparral & 3.2 \\
\hline L.S.D. (0.05) & Midnight & 3.0 & Cocktail & 3.2 \\
\hline
\end{tabular}

fine fescues had a thatch level higher than that commonly considered acceptable $(1 \mathrm{~cm})$. This result confirmed previous informations about thatch layer in fine fescues lawns (Duble, 2001) and in turfgrass mixtures containing Kentucky bluegrass (Dunn et al., 1994).

Although some differences in thatch thickness were observed between trafficked and nontrafficked plots, wear treatment did not produce a thatch layer significantly lower than that measured in non-trafficked plots. On the contrary, Dunn et al. (1994) found that thatch thickness in trafficked turf $(1.9 \mathrm{~cm})$ was significantly lower than that measured in non-trafficked turf (3.3 $\mathrm{cm})$, but a three-year heavier traffic treatment was applied in their work.

The traffic treatment by species interaction effect on thatch thickness was also not significant.

\section{Conclusions}

The assessment of variation in wear tolerance among cool-season turfgrass species and cultivars indicated that selection to improve wear tolerance may be feasible. Results of this study highlighted that turfgrass species tolerated traffic stress in different ways: through leaves with a major mechanical strength, cultivars that formed denser turf, and a good recovery potential after wear injury.
Tall fescue and perennial ryegrass showed the best wear tolerance and they could be used for implementation of different types of turf in Central Italy. The limited variation among their varieties indicated that almost all tested cultivars could be selected for both trafficked and non-trafficked turfgrasses. Kentucky bluegrass showed good traffic tolerance and Cynthia, Midnight and Haga were its best cultivars to use in sport fields and recreational areas. Fine fescue species showed the lowest turfgrass quality under traffic so that their utilization could be useful only in the ornamental lawns with high management levels. These results provide a valuable resource when managers of sports fields, parks, golf courses and other recreational areas are faced with the decision as to which turfgrass species and varieties to establish or overseed.

\section{References}

Allen R.G., Smith M., Pereira L.S., Perrier A. 1994. An update for the calculation of reference evapotranspiration. ICID Bull., 43, 2:35-92.

Allen R.G., Pereira L.S., Raes D., Smith M. 1998. Crop evapotranspiration: Guidelines for computing crop water requirements. Irr. \& Drain. Paper 56. FAO, Rome, Italy.

Bonos S.A., Watkins E., Honig J.A., Sosa M., Molnar T., Murphy J.A., Meyer W.A. 2001. Breeding cool-season turfgrasses for wear tolerance using a wear simulator. Int. Turfgrass Soc. Res. J., 9:137-145. 
Bonos S.A., Dickson W.K., Park B.S., Watkins E., Bara R.F., Smith D.A., Wilson M.M., Lawson T.J., Clark J., Murphy J.A., Funk C.R., Meyer W.A. 2003. Performance of Kentucky bluegrass cultivars and selections in New Jersey turf trials. Rutgers Turfgrass Proceedings, 35:45-111.

Bourgoin B., Mansat P. 1982. Artificial trampling and players traffic on turfgrass mixtures. Resen-TurfGazon, 4:72-79.

Brown P.W., Mancino C.F., Young M.H., Thompson T.L., Wierenga P.J., Kopec D.M. 2001. Penman Monteith Crop Coefficient for Use with Desert Turf Systems. Crop Science, 41:1197-1206.

Canaway P.M. 1981. Wear tolerance of turfgrass species. J. Sports Turf Res. Inst., 57:108-121.

Carrow R.N. 1980. Influence of soil compaction on three turfgrass species. Agron. J. 72:1038-1042.

Cereti C.F. 2002. Tappeti erbosi e inerbimenti. In: Baldoni R., Giardini L.: Coltivazioni erbacee - Foraggere e tappeti erbosi, 354. Pàtron Editore, Bologna.

Cereti C.F., Reyneri A., Bruno G. 2002. Il tappeto erboso per il gioco del calcio: indagine sulla situazione degli impianti italiani. I. Caratteristiche del substrato e del tappeto erboso. Acer, 6:34-39.

Cereti C.F., Reyneri A., Bruno G. 2003. Il tappeto erboso per il gioco del calcio: indagine sulla situazione degli impianti italiani. II. Relazioni tra le tecniche costruttive, manutentive e l'utilizzazione. Acer. 1:42-49.

Cockerham S.T., Brinkman D.J. 1989. A simulator for cleated-shoe sports traffic on turfgrass research plots. Calif. Turfgrass Culture, 39, 3-4:9-10.

Duble R.L. 2001. Turfgrasses: Their Management and Use in the Southern Zone, 195. Texas A\&M University Press.

Dunn J.H., Minner D.D., Fresenburg B.F., Bughrara S.S. 1994. Bermudagrass and cool-season turfgrass misture: response to simulated traffic. Agron. J., 86: 10-15.

Evans G.E. 1988. Tolerance of selected bluegrass and fescue taxa to simulated human foot traffic. J. Environ. Hort, 6, 1:10-14.

Fushtey S.G., Taylor D.K., Fairey D. 1982. The effect of wear stress on survival of turfgrass in pure stands and in mixtures. Can J. Plant Sci., 63:317-322.

Gaussoin R.E. 1994. Choosing traffic-tolerant turfgrass varieties. Sports Turf, 10:25-26.

Meyer J.L., Gibeault V.A., Youngner V.B. 1985. Irrigation of turfgrass below replacement of evapotranspiration as a means of water conservation: determining crop coefficient of turfgrasses. In: Lemaire F. (ed.): Proceedings $5^{\text {th }}$ Int. Turfgrass Res. Conf., 1-5 July, Avignon, France, 357-364.

Minner D.D., Dunn J.H., Bughrara S.S., Fresenburg B.S. 1993. Traffic tolerance among cultivars of Kentucky bluegrass, tall fescue, and perennial ryegrass. Int. Turf
Soc. Res. J., 7:687-694. In: Carrow R.N., Christians N.E., Shearman R.C. (eds.): Intertec Publishing Corp., Overland Park, Kansas.

Noè N., Passini R. 2009. Naturalmente sportivi. Acer, 2:26-31.

O’Neil K.J., Carrow R.N. 1982. Kentucky bluegrass growth and water use under different soil compaction and irrigations regimes. Agron. J., 74:933-936.

O’Neil K.J., Carrow R.N. 1983. Perennial ryegrass growth, water use, and soil aeration status under soil compaction. Agron. J., 75:177-180.

Park B.S., Murphy J.A., Meyer W.A., Bonos S.A., den Haan J., Smith D.A., Lawson T.J. 2003. Traffic tolerance of cool-season turfgrasses. 2003 Rutgers Turfgrass Proceedings, 199-219.

Park B.S., Murphy J.A., Lawson T.J., Devaney J.E., Dickson W.K., Clark J.B., Bonos S.A., Meyer W.A. 2006. Assesment of Kentucky bluegrass subjected to fallapplied wear. 2006 Rutgers Turfgrass Proceedings, 179-196.

Parr T.W. 1981. A population study of a sports turf system. In: R.W. Sheard (ed.): Proceedings $4^{\text {th }}$ Int. Turfgrass Res. Conf., Ontario Agricultural College, Guelph, Canada, 143-150.

Reyneri A., Bruno G. 2003. The effect of wear on three soils and two turfgrass mixtures for soccer grounds. In: Nektarios P.A. (ed.): Acta Hort 661, ISHS 2004. Proceedings of the First Int. Conf. on Turfgrass Management and Science for Sport Fields, 2-7 June 2003, Athens, Greece, 49-52.

Richie W.E., Green R.L., Klein G.J., Hartin J.S. 2002. Tall Fescue Performance Influenced by Irrigation Scheduling, Cultivar, and Mowing Height. Crop Science, 42:2011-2017.

Shearman R.C., Beard J.B. 1975. Turfgrass wear tolerance mechanisms. Agron. J., 67:208-211.

Shildrick J.P. 1974. Wear tolerance of turfgrass cultivars in the United Kingdom. Proceedings of the $2^{\text {nd }}$ Int. Turfgrass Res. Conf., 25-34.

Shildrick J.P., Peel C.H. 1984a. Shoot numbers, biomass and shear strength in smooth-stalked meadow-grass (Poa pratensis). J. Sports Turf Res. Inst., 60:66-72.

Shildrick J.P., Peel C.H. 1984b. Preliminary trials of perennial ryegrass cultivars (Trials A1, B2, and B3), 1980-3. J. Sports Turf Res. Inst., 60:73-95.

Taivalmaa S.L., Talvitie H., Jauhiainen L., Niemelainen O. 1998. Influence of wear-stress on turfgrass species and cultivars in Finland. J. Turfgrass Sci., 74:52-62.

Trenholm L.E., Carrow R.N., Duncan R.R. 2000. Mechanisms of wear tolerance in seashore paspalum and bermudagrass. Crop Sci., 40:1350-1357.

Wood G.M., Law A.G. 1972. Evaluating Kentucky bluegrass cultivars for wear resistance. In: 1972 Agronomy abstracts, 65. ASA, Madison, WI. 